IZA DP No. 4246

Unionization and the Evolution of the Wage Distribution in Sweden: 1968 to 2000

James Albrecht

Anders Björklund

Susan Vroman

June 2009 


\title{
Unionization and the Evolution of the Wage Distribution in Sweden: 1968 to 2000
}

\author{
James Albrecht \\ Georgetown University and IZA \\ Anders Björklund \\ SOFI, Stockholm University and IZA \\ Susan Vroman \\ Georgetown University and IZA
}
Discussion Paper No. 4246
June 2009

\author{
IZA \\ P.O. Box 7240 \\ 53072 Bonn \\ Germany \\ Phone: +49-228-3894-0 \\ Fax: +49-228-3894-180 \\ E-mail: iza@iza.org
}

\begin{abstract}
Any opinions expressed here are those of the author(s) and not those of IZA. Research published in this series may include views on policy, but the institute itself takes no institutional policy positions.

The Institute for the Study of Labor (IZA) in Bonn is a local and virtual international research center and a place of communication between science, politics and business. IZA is an independent nonprofit organization supported by Deutsche Post Foundation. The center is associated with the University of Bonn and offers a stimulating research environment through its international network, workshops and conferences, data service, project support, research visits and doctoral program. IZA engages in (i) original and internationally competitive research in all fields of labor economics, (ii) development of policy concepts, and (iii) dissemination of research results and concepts to the interested public.
\end{abstract}

IZA Discussion Papers often represent preliminary work and are circulated to encourage discussion. Citation of such a paper should account for its provisional character. A revised version may be available directly from the author. 


\section{ABSTRACT \\ Unionization and the Evolution of the Wage Distribution in Sweden: 1968 to $2000^{*}$}

We examine the evolution of the Swedish wage distribution over the periods 1968-1981 and 1981-2000. The first period was the heyday of the Swedish solidarity wage policy with strongly equalization clauses in the central wage agreements. During the second period, there was more scope for firm-specific factors to affect wages. We find a remarkable compression of wages across the distribution in the first period, but in the second period, wage growth was quite uniform across the distribution. We decompose these changes across the distribution into two components - those due to changes in the distribution of characteristics such as education and experience and those due to changes in the distribution of returns to those characteristics. The wage compression between 1968 and 1981 was driven by changes in the distribution of returns, but between 1981 and 2000, the change in the distribution of returns was neutral with respect to inequality.

JEL Classification: J31, J51

Keywords: wage compression, unionization, quantile regression

Corresponding author:

James Albrecht

Department of Economics

Georgetown University

Washington, DC 20057

USA

E-mail: albrecht@georgetown.edu

\footnotetext{
* We acknowledge financial support from the Swedish Council for Working Life and Social Research (FAS). Useful comments were received at the annual meetings of the European Society for Population Economics.
} 


\section{Introduction}

The final third of the twentieth century represents an important episode in Swedish labor market history. Over that period, the pattern of unionization and the influence of unions on the wage distribution changed in interesting ways. From 1968-1983 the unionization rate increased sharply in Sweden, and unions gained more power to influence the wage distribution. These years were characterized by "solidarity wage bargaining," in which a pattern of centralized negotiations allowed unions to exert pressure to raise the relative wages of the least well paid. This was a period of strong wage compression. However, starting in 1983, the system of centralized bargaining started to fall apart. The fraction of workers covered by the Central Confederation of Blue-Collar Unions (LO), which had been the driving force behind solidarity wage bargaining, fell. The fraction of workers covered by the umbrella confederations representing white-collar workers (TCO and SACO) increased, as did the fraction of nonunion workers. From 1983-2000, the wage distribution in Sweden changed only in relatively minor ways - a bit more compression at the bottom of the distribution, a bit more spreading out at the top. In a comparative perspective, this stability is remarkable since many other countries experienced substantial increases in wage inequality over this period.

In this paper, we analyze changes in the Swedish wage distribution between 1968 and 2000. We investigate the extent to which changes in the wage distribution can be accounted for by changes in the pattern of unionization (LO versus TCO/SACO versus nonunion) and in the distribution of other workforce characteristics (education, etc.). At the same time, we take into account that movements in the distribution of returns to union membership and other workforce characteristics also led to changes in the wage distribution over this period.

To address this issue, we use the Machado and Mata (2005) technique to decompose the change in the log wage distribution between any two years into two components - the effect of the change in the distribution of characteristics and the effect of the change in the distribution of returns to these characteristics. This is done by simulating a counterfactual distribution of the wages that would have been earned if the distribution of 
characteristics had remained the same between the two years and only the distribution of returns to these characteristics had changed. We carry out our analysis using data from the 1968, 1981 and 2000 waves of the Swedish Level of Living Survey (LNU); in particular, we first compare 1981 to 1968 and then 2000 to 1981.

Between 1968 and 1981, the change in the distribution of labor market characteristics had a uniformly positive effect on the log wage distribution. However, the change in the shape of the wage distribution between these two years was driven primarily by the change in the distribution of returns. In the lower half of the distribution, the returns to characteristics increased sharply between 1968 and 1981, and this had a strong positive effect on the wages of the least well paid. In the upper quartile of the distribution, the change in the distribution of returns between the two years worked to decrease the wages of the best paid workers. We interpret this change in the distribution of returns primarily as the result of the solidarity wage policy. That is, absent the solidarity wage policy, wages would have increased more or less uniformly throughout the distribution, but the tilt in the distribution towards the least well paid reflects this policy.

Between 1981 and 2000, the increase in wages was considerably more uniform across the distribution. The only exceptions were at the lowest quantiles - the relative wages of the least well paid increased from 1981 to 2000 - and at the highest quantiles the relative wages of the best paid workers also increased between these two years. The effect of the change in the distribution of returns dominates that of the change in the distribution of characteristics across all quantiles, although both effects are important. This is particularly true at the extremes; i.e., the compression at the bottom of the distribution and the spreading out at the top of the distribution are driven primarily by returns. That is, in Sweden, the wages of the least well paid did not fall in relative terms as happened elsewhere, but some of the spreading out at the top that has been observed in other countries also occurred in Sweden.

The outline of the rest of the paper is as follows. In the next section, we give some institutional background and explain why we expect to see a relationship between the pattern of unionization and the wage distribution. In Section 3, we describe the Swedish Level of Living Survey and present some descriptive results. In Section 4, we report the results of quantile regressions of log wage on individual characteristics, including union 
membership. These quantile regressions are inputs to the Machado/Mata procedure - the collection of quantile regression coefficients represents the distribution of rewards to characteristics. Finally, in Section 5, we explain the Machado-Mata method and then use it to decompose changes in the wage distribution between 1968 and 1981 and between 1981 and 2000 into the two components discussed above.

\section{The Wage-Setting Institutions}

We begin with some broad facts about unionization in Sweden. The union density rate in Sweden was very high by international standards over the entire 1968-2000 period; indeed, available cross-national comparisons suggest that Sweden's union density rate was higher than in any other country during this period. The development of the Swedish union density rate over this period was more or less the mirror image of the development in the United States.

Table 1 goes here

At the same time, the union density rate did not increase uniformly in Sweden over this period. As can be seen in both Tables 1 and 2, this rate reached its peak sometime after 1980 , declining thereafter. ${ }^{1}$ Table 2 also shows a significant change in the pattern of union membership over time. In 1968, about 65\% of union members were affiliated with LO. By 1981, although the fraction of the workforce affiliated with LO increased slightly, the rate of growth in TCO/SACO membership was considerably stronger, so LO members as a fraction of the unionized workforce fell to less than $60 \%$. Finally, by 2000 , LO membership had declined substantially, both as a fraction of the workforce and as a fraction of union membership (less than $50 \%$ ).

Table 2 goes here

\footnotetext{
${ }^{1}$ Tables 1 and 2 show different Swedish unionization rates in 2000. The discrepancy is due to the fact that we do not include self-employed workers in the LNU data.
} 
In short, although the union density rate was high over the entire 1968-2000 period in Sweden, it did not grow monotonically, and the mix of union membership (LO versus TCO/SACO) changed substantially over time. To understand why these changes potentially matter for the overall wage distribution, we now give some institutional detail about wage setting in different occupations and sectors. ${ }^{2}$

\section{Blue-collar workers, private sector}

The solidarity wage policy is mainly associated with LO. During the 1966-1983 period, LO negotiated central frame agreements with the Swedish Employers Federation, SAF. These agreements covered around 800,000 LO-members in the private sector, or around 20 percent of the total labor force. They specified minimum contractual wage increases at the level of the individual worker. They were followed by negotiations at the industry and plant levels, which could result in additional wage increases and also concerned other aspects of work conditions. The central contracts had a number of characteristics that raised wages for workers in the bottom of the distribution:

i. A common flat rate of increase specified in öre (instead of relative wage increases) going to each worker.

ii. "Wage drift" guarantee amounts that compensated those workers who had not benefited from market wage drift since the previous wage agreement.

iii. Cost of living adjustments that were usually paid as a flat rate.

iv. Low wage adjustment amounts. These wage adjustments were earmarked for workers with hourly wages below a certain reference wage (låglönegräns) and were paid as a fraction of the difference between the worker's actual wage and the reference wage.

These characteristics of the centrally negotiated contracts implied much larger wage increases for workers in the bottom of the distribution than for those further up in the distribution. In their detailed analysis of these contracts, Hibbs and Locking (1996, Figure 1) simulated the implications of the contracts using the actual wage structure. They found that the implied relative wage increases over the period 1972 to 1982 were

\footnotetext{
${ }^{2}$ See Elvander (1997), Hibbs (1990), Hibbs and Locking (1996) and references therein for more details about Sweden's wage setting institutions over this period.
} 
about three times higher for workers in the bottom decile than for the median worker, who in turn could expect around a 50 percent higher wage increase than workers in the top decile.

Although the central agreements specified wage increases at the level of the individual worker, subsequent negotiations at the industry and plant levels allowed for other forces to affect actual wage increases. Substantial wage increases in addition to the centrally agreed ones were sometimes negotiated. It is these wage increases that became known as wage drift. It is likely that traditional market forces affected wage drift. The question then is how market forces acting through wage drift interacted with the equalizing effects of the centrally negotiated agreements.

The era of more decentralized wage bargaining and less emphasis on special lowwage settlements started in 1983 when the Swedish Metal Workers' Union (Metall) concluded a separate agreement with the Swedish Engineering Employers' Association (Verkstadsföreningen). At that time, Metall was a powerful union within LO, and Verkstadsföreningen a leading member association in SAF. The remaining parts of the SAF-LO area were covered by a central agreement.

In the following years, wage bargaining took place without central coordination between SAF and LO. The most common bargaining structure has been one of central agreements at the industry level without much co-ordination across the industries. Agreements at the industry level have been followed by agreements at the plant level. The scope for industry and firm specific factors to affect the wage structure has consequently increased. Although contracts often stipulated a guaranteed absolute wage increase for all workers, and hence higher relative wage increases in the lower end of the wage distribution, the special low-wage settlements that characterized the central frame agreements were no longer used.

\section{White-collar workers, private sector}

Unions for white-collar workers belong to either of two central organizations, namely, the Central Organization of Salaried Employees (TCO) or the Swedish Confederation of Professional Associations (SACO). Unlike LO, these central organizations, with a few exceptions, have not participated in collective bargaining at the 
central level. For private-sector bargaining with SAF, a number of TCO and SACO unions formed a group called the Federation of Salaried Employees in Industry and Services (PTK). From the late 1960s until 1988, SAF and PTK were the main actors who negotiated the central frame agreements for white-collar workers in the private sector.

The agreements between SAF and PTK have not been scrutinized with the same detail as Hibbs and Locking (1996) did for the SAF-LO part of the labor market. There is no doubt that these agreements also had provisions that raised wages in the bottom of the distribution more than in the top, but these central agreements did not specify wage increases at the level of the individual worker in the way that the SAF-LO contracts did. ${ }^{3}$ Our reading of the literature and informal interviews with industrial relations experts suggest that these contracts left more room for individual wage variation and more scope for wage drift. Thus, the contracts in this part of the labor market had somewhat weaker equalization effects than the SAF-LO contracts did. Finally, we note that the trend in wage-bargaining institutions since the 1980s is the same in this part of the labor market as the other, namely towards more decentralization.

\section{The public sector}

The public sector has three central employer organizations: one for the central government, one for municipalities, and one for the county councils. During the peak period of centralized wage bargaining, TCO and SACO (and two LO unions) had separate bargaining groups for this sector of the labor market. The central agreements in the public sector had very strong low-wage provisions. It is also likely that these agreements had a particularly strong impact on the final wage structure in the public sector. The reason is that wage drift is not regarded as a relatively important phenomenon in the public sector. In particular, piece rates and bonus pay, which are more difficult to regulate with central agreements, are used relatively infrequently in the public sector. We believe therefore that contracts in the public sector also had a strong equalizing effect and upward pressure on the very low wages was particularly strong. However, in common

\footnotetext{
${ }^{3}$ This is what makes it difficult to simulate the implications of the SAF-PTK agreements in the same way as Hibbs and Locking (1996) did for the SAF-LO agreements.
} 
with the rest of the labor market, the trend towards decentralization has been very strong in the public sector since the late 1980s.

\section{The nonunion sector}

By tradition, agreements between a local union and a firm should also be valid for nonunion workers with jobs that are like those of the union workers. Nonetheless, it is interesting to note that the only Swedish study of union wage gaps (D’Agostino 1992) found significant union effects for blue-collar workers ranging from 12 to 24 percent over the period 1968 to 1981. Thus, despite the tradition of imposing union contracts on nonunion workers, there seems to be differential treatment of union and nonunion workers. We conjecture therefore that there is more room for individual and firm-specific factors to affect wages of nonunion workers. In addition, nonunion workers form a quite heterogeneous group with both temporary labor force participants, who do not have incentives to join a union, and managers, who may have more in common with owners than with other employees.

\section{Data and Descriptive Patterns}

$\underline{\text { Data }}$

We use the Level of Living Surveys conducted in 1968, 1981, and 2000 (see Erikson and Åberg , 1987). The LNU data are also available for 1974 and 1991, but, given our focus, it suffices to use only 1968, 1981, and 2000. The LNU data are the most commonly used in previous studies of the Swedish wage structure. These surveys are representative of the Swedish population (ages 15 to 75, except in 2000 when the lower age limit was 19). We only use data on workers 19-65 in order to be consistent across the years. We eliminate the self employed since hourly wage information is not available for this group. We also eliminate immigrants because there were too few in the 1968 data for our analysis. Finally, the LNU dataset is a panel, but we do not use that property in this study.

These surveys ask direct questions about key variables such as earnings, working hours, years of schooling and work experience, tenure with the present employer and 
union membership. In these data, the hourly wage is measured using information from a sequence of questions. A question is first asked about the mode of pay, whether it is by hour, by week, by month, by piece rate, etc. Conditional on the answer to this question, the next question is about the pay per hour, the pay per week, etc. Finally, information about normal working hours is used to compute hourly wages for those who are not paid by the hour. The surveys also ask about union membership. First, the sampled person is asked whether he or she is a union member. In case of an affirmative answer, the next question is to what union the person belongs.

\section{Descriptive patterns}

Table 3 presents sample descriptive statistics by union status for each of the three years. Looking first at the log real wage (expressed in 1968 Swedish crowns), there is wage growth across all categories, both from 1968 to 1981 and from 1981 to 2000. In terms of wage dispersion, the standard deviation of the log wage is lowest among LO members and highest among nonunion workers in all three years. This standard deviation falls across all worker categories between 1968 and 1981. This change is least pronounced among LO workers. The pattern is different for 1981 to 2000. In this period, there was a continued decrease in inequality among LO members. This occurred despite the demise of solidarity wage bargaining over this period, perhaps reflecting an increased homogeneity among LO membership. Over the same period, wage inequality among TCO/SACO members was essentially unchanged. Over the whole period, there was a remarkable change in the position of nonunion workers in the wage distribution. In 1968 nonunion workers had 0.10 log points lower average wage than LO-workers and over $0.40 \log$ points lower than TCO/SACO-workers, but in 2000 this had changed to 0.16 log points above LO-workers and only 0.05 log points below TCO/SACO workers.

Table 3 goes here

In addition to union status, the variables that we use to explain the log wage are gender, years of work experience, years of tenure on the current job, years of education, 
and sector (private versus public). The most notable trends in these variables between 1968 and 1981 are the increase in the fraction of the workforce that is female and the decline in the relative importance of private-sector employment. These two developments are related as women are more likely than men to work in the public sector. Since public sector employees are more likely to be unionized than their private sector counterparts this also means that women are somewhat more likely to be union members than men are. Between 1981 and 2000, the most striking changes are among nonunion workers. These workers are considerably more likely to be male, in the private sector and highly educated in 2000 as compared to 1981.

Figures 1-3 go here

The evolution of the wage distribution that is broadly summarized in Table 3 can be seen in more detail in Figures 1-3. The log wages that underlie these figures (and the other figures presented later) are all expressed in 1968 SEK. Figure 1 shows estimated kernel densities for 1968, 1981 and 2000. The rightward shift in these kernels represents the productivity growth realized over this period. Our focus, however, is on the change in the shape of the log wage distribution, which clearly becomes more compressed in the period after 1968.

Figure 2 shows the difference between the 1981 and 1968 log wage distributions on a quantile-by-quantile basis. (The bands around the difference give the $95 \%$ confidence interval.) The workers toward the bottom of the 1981 log wage distribution were paid considerably more (about $47 \%$ more at the $5^{\text {th }}$ percentile) than were the least well-paid workers in the $1968 \log$ wage distribution. The workers toward the top of the $1981 \log$ wage distribution were also paid more (about 4 percent at the $95^{\text {th }}$ percentile) than were the best-paid workers in the 1968 log wage distribution, but this difference is clearly much smaller than at the bottom of the distribution. Another way to express this is to say that Figure 2 shows the difference between the estimated quantiles of the 1981 and 1968 log wage distributions. The fact that this difference is strongly downward sloping indicates substantial wage compression between 1968 and 1981. 
Figure 3 shows the difference between the 2000 and 1981 log wage distributions. Between the $5^{\text {th }}$ and the $95^{\text {th }}$ percentiles, this difference shows a slight but steady increase; that is, there was a weak increase in dispersion across most of the distribution. At the very lowest quantiles, the difference between the two distributions is particularly large, and at the very highest quantiles, the growth in the real wage was above average. That is, there was some compression between 1981 and 2000 at the very bottom of the distribution coupled with some pulling apart at the very top of the distribution.

The difference in wage growth between the workers at the $5^{\text {th }}$ and $95^{\text {th }}$ percentiles is only about 3 percentage points. In a cross-national perspective, this is strikingly low for this period, which was one of rapidly rising wage inequality in many countries. For example, Autor et al. (2008, Figure 11B) report a corresponding difference in wage growth of about 20 percentage points for the United States. Dustmann et al. (2009, Figure III) also report large increases in inequality for Germany over this period.

\section{Quantile Regression Results}

Figures 2 and 3 show differences between unconditional log wage distributions. The next step therefore is to look at conditional log wage distributions. To do this, we estimate a series of quantile regressions. We assume linearity, i.e., that the $\mathrm{q}^{\text {th }}$ quantile of the log wage distribution in year $t$ conditional on characteristics is linear in those variables:

$$
\operatorname{Quant}_{q}\left(Y_{t} \mid X_{t}=x_{t}\right)=x_{t} \beta(q)
$$

Given the linearity assumption, the quantile regression coefficients $\left\{\beta_{\mathrm{t}}(\mathrm{q}): 0<\mathrm{q}<1\right\}$ completely characterize the distribution of log wages in year $t$ conditional on characteristics X.

We first present the summary results of a series of simple quantile regressions in which we condition only on an LO and a TCO/SACO dummy. Table 4 presents the quantile regression results at the $10^{\text {th }}, 50^{\text {th }}$, and $90^{\text {th }}$ percentiles for 1968,1981 and 2000. For comparison, the OLS results are also presented for each of the three years. We emphasize that, of course, the LO and TCO/SACO indicators, are arguably endogenous. This means that the coefficient estimates presented in Table 4 should be interpreted as the returns "associated with" union status, and not as the causal effect of union membership 
on the log wage. These estimates presumably also reflect the fact that $\mathrm{LO}$ and TCO/SACO members differ from each other and from nonunion workers in terms of relevant observables and unobservables. However, from the point of view of the Machado-Mata analysis to be presented in the next section, endogeneity is not an issue. The estimated quantile regression coefficients characterize the distribution of the log wage conditional on the explanatory variables in each of the three years, and they do so irrespective of whether the estimates reflect the "true" casual effect of these variables.

Table 4 goes here

The pattern shown in Table 4 is straightforward. There are positive returns to LO membership in the bottom half of the distribution, but there is a penalty associated with LO membership in the highest percentiles. Over time, the returns to LO membership have fallen across the distribution. There are positive returns to TCO/SACO membership (except at the $90^{\text {th }}$ percentile in 2000), especially in the lower percentiles. These returns have fallen over time, and the fall is discernible over the whole distribution. Finally, we also note that the narrowing between LO and TCO/SACO workers between 1968 and 1981 predominantly took place in the upper part of the distribution.

Table 5 goes here

Of course, some of the "returns" to union status reflect the fact that LO members, TCO/SACO members and nonunion workers do not have the same characteristics. To control for this as best we can, we use the variables presented in Table 3 as explanatory variables, i.e., union status, a gender dummy, years of work experience, years of work experience squared (divided by 100), years of tenure, years of education, and a sector dummy. The results of these quantile regressions are presented in Table 5. First, holding all the other observables constant, the premium associated with LO is now only positive at the $10^{\text {th }}$ percentile, although these coefficients are lower than the corresponding ones in Table 4. It is still the case that the LO returns fall over time. The returns to TCO/SACO membership are also smaller than in Table 4 and are now negative at the $90^{\text {th }}$ percentile in 
all years. Second, the pattern of coefficient estimates for the explanatory variables is standard. There is a significant premium for males, which increases most as we move from the median to the $90^{\text {th }}$ percentile. This is the "glass ceiling” pattern discussed in Albrecht et al. (2003). The returns to years of work experience are positive (but small) and concave; similarly, the returns to tenure are positive, as expected. The returns to education are positive and increase as we move up the distribution. Finally, and perhaps unexpectedly, the coefficient on the dummy for private sector employment moves from negative across the distribution in 1968 to strongly positive in 2000.

It is also worth noting that the returns to being male, to education and to experience all fall dramatically between 1968 and 1981. We interpret this as reflecting the solidarity wage policy. This interpretation is also given in Edin and Holmlund (1995), although they also emphasize the increased supply of university graduates over this period. The returns to gender, education and experience remain low in 2000.

\section{Machado-Mata Analysis}

In this section, we use the method of Machado and Mata (2005) to address questions such as "What would the log wage gap between 1981 and 1968 have been if the distribution of labor market characteristics had not changed during that period?” That is, to what extent can we account for the observed gap between the 1981 and 1968 distributions -as shown in Figure 2 - by the change in the distribution of observables, and to what extent is the gap due to a change in the distribution of returns to those observables between those two years?

The Machado-Mata method can be understood most easily by considering the following artificial problem. Consider a random variable $\mathrm{Y}$ with distribution function $\mathrm{F}(\mathrm{y})$. Let the corresponding explanatory variables $\mathrm{X}$ have distribution function $\mathrm{G}(\mathrm{x})$. Suppose we have a sample on $(\mathrm{Y}, \mathrm{X})$. Write

$$
F(y)=\int F(y \mid x) d G(x)
$$

Using the assumption that the conditional quantiles of $\mathrm{Y}$ given $\mathrm{X}=\mathrm{x}$ are linear in $\mathrm{x}$, the conditional distribution of $\mathrm{Y}$ given $\mathrm{X}=\mathrm{x}$ is completely described by the collection of quantile regression coefficients, i.e., the $\{\beta(q): 0<q<1\}$. One can then simulate a draw 
from $F(y)$ by (i) drawing a value of $q$ at random from [0,1] and estimating $\beta(q)$, (ii) drawing a value of $\mathrm{x}$ at random from the empirical distribution of $\mathrm{X}$, and (iii) multiplying the two to generate a simulated value $y$. Repeating this process many times simulates draws from $\mathrm{F}(\mathrm{y})$.

The simulation problem just described is artificial in the sense that there is no need to simulate $\mathrm{F}(\mathrm{y})$ - we already had a sample from that distribution. The same reasoning, however, can be used to simulate "counterfactual” distributions. Suppose we are interested in the distribution of log wages that we would expect to observe if workers had the year $t$ distribution of X's but the year s distribution of returns. Call this counterfactual random variable $\mathrm{Y}_{\mathrm{t}, \mathrm{s}}$. The distribution function of this random variable is

$$
F_{t, s}(y)=\int F_{s}(y \mid x) d G_{t}(x)
$$

Draws from $\mathrm{F}_{\mathrm{t}, \mathrm{s}}(\mathrm{y})$ can be simulated by (i) drawing a value of $\mathrm{q}$ at random from $[0,1]$ and estimating $\beta_{\mathrm{s}}(\mathrm{q})$, (ii) drawing a value of $\mathrm{x}$ at random from the year $\mathrm{t}$ sample distribution of observables, and (iii) multiplying the two to generate a simulated value of $\mathrm{y}$. Again, repeating this process many times simulates draws from $\mathrm{F}_{\mathrm{t}, \mathrm{s}}(\mathrm{y}){ }^{4}$ Similarly, the Machado-Mata procedure can be used to simulate draws from $\mathrm{F}_{\mathrm{s}, \mathrm{t}}(\mathrm{y})$, the distribution of log wages that we would expect to observe if workers had the year s distribution of X's and the year $\mathrm{t}$ distribution of returns.

We first apply this technique to the gap between the distributions of real log wages in 1981 versus 1968, i.e., to analyze the pattern of change exhibited in Figure 2. Figure 4 presents the counterfactual gap that gives the difference between the observed 1981

\footnotetext{
${ }^{4}$ This description of the simulation procedure follows Machado and Mata (2005). Standard errors for the estimated quantiles of the counterfactual distribution that is generated in this way can be found by bootstrapping, as described in Machado and Mata (2005), or by applying the asymptotic results given in Albrecht et al. (2009). An alternative procedure for simulating $\mathrm{F}_{\mathrm{t}, \mathrm{s}}(\mathrm{y})$ is as follows:

(i) Estimate $\beta_{\mathrm{s}}(\mathrm{q})$ for a grid of values, e.g., $\mathrm{q}=0.01,0.02$, etc.

(ii) Multiply each estimated quantile regression coefficient vector by each $\mathrm{x}$ in year t's empirical distribution of observables.

Variations on this alternative procedure have been used by Albrecht et al. (2003), Autor et al. (2005) and Melly (2007). Standard errors for the estimated quantiles of the counterfactual distribution that is generated using this alternative procedure can again be found by bootstrapping or by applying the asymptotic results given in Melly (2007). The results presented in this paper were generated using a STATA program written by Blaise Melly. This program implements the procedure described in this footnote and gives bootstrapped standard errors. We have replicated our results using the STATA program written by Aico van Vuuren. This program implements the original Machado and Mata (2005) algorithm and gives the asymptotic standard errors derived in Albrecht et al. (2009). The results using the two different programs are essentially identical.
} 
distribution and the counterfactual distribution that is constructed by simulating the distribution of wages that we would expect to have observed for a group of workers with the 1981 distribution of labor market characteristics but receiving 1968 returns to those characteristics. The bands around the gap shown in this figure are the $95 \%$ confidence intervals. The same pattern is shown in the first panel of Table 6, which gives the estimated gaps (raw and counterfactual) between the 1968 and 1981 log wage distributions together with the associated standard errors at various quantiles.

Figure 4 goes here

Table 6 goes here

As can be seen by comparing Figures 2 and 4 (or by examining the first panel in Table 6), the qualitative shape of the quantile-by-quantile differences in log wages between 1968 and 1981 is driven by the change in the distribution of returns to labor market characteristics between these two years. To illustrate the decomposition of this log wage gap more clearly, Figure 5 combines Figures 2 (marked by dots) and 4 (marked by triangles) along with a curve (marked by diamonds) that illustrates the contribution of the change in the distribution of observable labor market characteristics.

Figure 5 goes here

Figure 5 can be understood as follows. The raw gap between the 1981 and $1968 \log$ wages at the $\mathrm{q}^{\text {th }}$ quantile can be expressed as Quant $_{q}\left(Y_{81}\right)-$ Quant $_{q}\left(Y_{68}\right)=$ Quant $_{q}\left(Y_{81}\right)-$ Quant $_{q}\left(Y_{81,68}\right)+$ Quant $_{q}\left(Y_{81,68}\right)-$ Quant $_{q}\left(Y_{68}\right)$ where $\mathrm{Y}_{81,68}$ is the counterfactual random variable simulated using the 1981 distribution of characteristics but the 1968 distribution of returns to those variables. The raw gap at the $\mathrm{q}^{\text {th }}$ quantile can be written as the sum of two components. The first term, $\mathrm{Quant}_{\mathrm{q}}\left(\mathrm{Y}_{81}\right)$ Quant $_{\mathrm{q}}\left(\mathrm{Y}_{81,68}\right)$, isolates the part of the raw gap that is due to the change in the distribution of returns between 1968 and 1981. The second term, Quant $_{q}\left(\mathrm{Y}_{81,68}\right)$ - Quant $_{q}\left(\mathrm{Y}_{68}\right)$, isolates 
the component due to the change in the distribution of characteristics between 1968 and 1981.

Figure 5 shows that if the distribution of returns had not changed between 1968 and 1981, the change in the distribution of characteristics would have generated a general increase in wages across the distribution - on the order of $8 \%$ around the $10^{\text {th }}$ quantile, around $10 \%$ at the median, and a bit more than $15 \%$ towards the top of the distribution. However, wage growth was lower in the top of the distribution, and this was entirely driven by the effect of returns. Thus, changes in the distribution of returns not only raised wages at the bottom of the distribution but also reduced wages at the top of the distribution relative to what they would have been. This led to a dramatic wage equalization.

Next, we apply this technique to the gap between the distributions of real log wages in 2000 versus 1981, i.e., to analyze the pattern of change exhibited in Figure 3. As can be seen in Figure 3, except at the extremes of the distribution - where the standard errors associated with the estimated raw gaps are large - wage growth rose slightly across the distribution. Figure 6 shows that the returns effect was essentially constant across the distribution. Further, Figure 7 shows that approximately three quarters of this growth can be attributed to returns. The same pattern can be seen in the second panel of Table 6 . We interpret this pattern as indicating that while the Swedish solidarity wage policy did not advance post-1981, neither were its effects scaled back.

\section{Conclusions}

We have explored the evolution of the wage distribution in Sweden during two periods, 1968-1981 and 1981-2000. The first period was characterized by a dramatic equalization of wages and the second by a weak increase in inequality. Using a quantile regression approach to decompose these changes into those attributable to changes in the distribution of returns and those attributable to changes in characteristics, we found that the equalization in 1968-1981 was mainly driven by changes in the distribution of returns, whereas the weak tendency toward inequality in the second period was driven by changes in the distribution of characteristics. 
These findings raise the question of what has driven the changes in the returns over the first period, and why the changes were so small during the second period. A natural candidate to explain the great equalization from 1968 to 1981 is the solidarity wage policy adhered to by Swedish unions. Previous research has mainly focused on the equalization among blue-collar workers (belonging to LO), whereas we also examined the white-collar workers (belonging to TCO/SACO). We found that equalization was substantial also among white-collar workers, a finding that is consistent with the wage policy of these unions. However, the narrowing of wage differentials between LO workers and TCO/SACO workers is harder to explain in this way. As suggested by Edin and Holmlund (1995), rising supply of college-educated workers might have been an additional (market) force that also contributed to wage compression in this period.

In a sense, it is a greater challenge to find a good explanation for the relatively stable wage structure during 1981-2000 since this was a period with dramatic changes in many other countries. One possible explanation is that Sweden could avoid the rise in wage inequality thanks to its high and equally distributed supply of labor-market relevant skills, as suggested by the results from the International Adult Literary Survey; see Björklund et al. (2005) and Fredriksson and Topel (2009) for expositions of Sweden's favorable scores in this survey. A quantile regression approach to these or similar data would be a promising route for future research.

\section{References:}

Albrecht, James, Anders Björklund, and Susan Vroman (2003), "Is There a Glass Ceiling in Sweden?” Journal of Labor Economics 21(1), 145-177.

Albrecht, James, Aico van Vuuren, and Susan Vroman (2009), "Counterfactual Distributions with Sample Selection Adjustments: Econometric Theory and an Application to the Netherlands," Labour Economics 16(4), 383-396, August 2009.

Autor, David, Lawrence Katz, and Melissa Kearney (2005), "Rising Wage Inequality: The Role of Composition and Prices,” NBER working paper 11628.

Autor, David, Lawrence Katz, and Melissa Kearney (2008), "Trends in U.S. Wage Inequality: Revising the Revisionists," Review of Economics and Statistics, 90(2), 300323. 
Björklund Anders, Melissa Clark, Per-Anders Edin and Alan Krueger (2005), The Market comes to Education - An Evaluation of Sweden's Surprising School Reforms, Russell Sage Foundation.

D’Agostino Hjördis (1992), "Why Do Workers Join Unions?,” Dissertation no. 22, Swedish Institute for Social Research, Stockholm University.

Dustmann, Christian, Johannes Ludsteck and Uta Schönberg (2009), Revisiting the German Wage Structure,” Quarterly Journal of Economics, 124(2), 843-881.

Edin, Per-Anders and Bertil Holmlund (1995), “The Swedish Wage Structure: The Rise and Fall of Solidarity Wage Policy?” in Richard Freeman and Lawrence Katz (eds.) Differences and Changes in Wage Structures. University of Chicago Press and NBER, Chicago IL.

Elvander, Nils (1997), The Swedish Bargaining System in the Melting Pot, Arbetslivsinstitutet, Solna.

Erikson, Robert and Rune Åberg (eds.) (1987), Welfare in Transition, Oxford: Clarendon Press.

Fredriksson, Peter and Robert Topel (2009), "Wage Determination and Employment in Sweden Since the Early 1990s - Wage Formation in a New Setting,” in Richard Freeman, Birgitta Swedenborg, and Robert Topel (eds), Reforming the Welfare State: Recovery and Beyond in Sweden, University of Chicago Press.

Hibbs, Douglas (1990), “Wage Dispersion and Trade Union Action in Sweden,”, in I. Persson (ed.) Generating Equality in the Welfare State: The Swedish Experience, Oslo: Norwegian University Press.

Hibbs, Douglas and Håkan Locking (1996), "Wage Compression, Wage Drift, and Wage Inflation in Sweden,” Labour Economics 3(2), 109-42.

Machado, José and José Mata (2005) “Counterfactual Decomposition of Changes in Wage Distributions using Quantile Regression,” Journal of Applied Econometrics, 20(4), 445-465.

Melly, Blaise (2007), “Estimation of Counterfactual Distributions Using Quantile Regression,” mimeo.

OECD (2004), Employment Outlook, OECD. 
Table 1: Union density rates in selected countries 1970-2000

\begin{tabular}{lllll}
\hline & 1970 & 1980 & 1990 & 2000 \\
\hline Sweden & 68 & 80 & 83 & 79 \\
Denmark & 60 & 76 & 71 & 74 \\
Finland & 51 & 70 & 72 & 76 \\
Norway & 51 & 57 & 56 & 54 \\
Canada & 31 & 36 & 36 & 28 \\
United Kingdom & 45 & 50 & 39 & 31 \\
\hline United States & 23 & 22 & 16 & 13 \\
\hline
\end{tabular}

Sources: OECD (2004).

Table 2: Unionization Rates in Sweden (from LNU)

\begin{tabular}{|l|l|l|l|}
\hline & 1968 & 1981 & 2000 \\
\hline LO & .462 & .494 & .402 \\
\hline TCO/SACO & .248 & .353 & .417 \\
\hline Nonunion & .290 & .153 & .181 \\
\hline
\end{tabular}

Source: Estimates from our sample of employed workers in the Level of Living Surveys. 
Table 3: Sample means (standard deviations in parentheses) by union status

\begin{tabular}{|c|c|c|c|c|c|c|c|c|c|}
\hline & \multicolumn{3}{|c|}{$1968(\mathrm{~N}=2893)$} & \multicolumn{3}{|c|}{$1981(\mathrm{~N}=3296)$} & \multicolumn{3}{|c|}{$2000(\mathrm{~N}=2980)$} \\
\hline & $\underline{\mathrm{LO}}$ & $\begin{array}{l}\underline{\mathrm{TCO} /} \\
\underline{\mathrm{SACO}}\end{array}$ & $\begin{array}{l}\underline{\text { Non- }} \\
\underline{\text { union }}\end{array}$ & $\underline{\mathrm{LO}}$ & $\begin{array}{l}\underline{\mathrm{TCO} /} \\
\underline{\mathrm{SACO}}\end{array}$ & $\begin{array}{l}\text { Non- } \\
\text { union }\end{array}$ & $\underline{\mathrm{LO}}$ & $\begin{array}{l}\underline{\mathrm{TCO} /} \\
\underline{\mathrm{SACO}}\end{array}$ & $\begin{array}{l}\text { Non- } \\
\text { union }\end{array}$ \\
\hline $\begin{array}{l}\text { Percent of } \\
\text { sample }\end{array}$ & 0.462 & 0.248 & 0.290 & 0.494 & 0.353 & 0.153 & 0.402 & 0.417 & 0.181 \\
\hline $\begin{array}{l}\text { Ln real } \\
\text { wage (1968 } \\
\text { SEK) }\end{array}$ & $\begin{array}{c}2.265 \\
(0.260)\end{array}$ & $\begin{array}{c}2.592 \\
(0.407)\end{array}$ & $\begin{array}{c}2.167 \\
(0.592)\end{array}$ & $\begin{array}{c}2.448 \\
(0.246)\end{array}$ & $\begin{array}{c}2.630 \\
(0.296)\end{array}$ & $\begin{array}{c}2.427 \\
(0.415)\end{array}$ & $\begin{array}{c}2.647 \\
(0.194)\end{array}$ & $\begin{array}{c}2.861 \\
(0.297)\end{array}$ & $\begin{array}{c}2.811 \\
(0.442)\end{array}$ \\
\hline $\begin{array}{l}\text { Percent } \\
\text { Male }\end{array}$ & 0.729 & 0.590 & 0.451 & 0.574 & 0.499 & 0.414 & 0.573 & 0.435 & 0.543 \\
\hline $\begin{array}{l}\text { Years of } \\
\text { work exp. }\end{array}$ & $\begin{array}{c}22.9 \\
(13.6)\end{array}$ & $\begin{array}{c}19.1 \\
(12.7)\end{array}$ & $\begin{array}{c}16.0 \\
(13.4)\end{array}$ & $\begin{array}{c}19.7 \\
(13.3)\end{array}$ & $\begin{array}{c}18.5 \\
(11.7)\end{array}$ & $\begin{array}{c}14.5 \\
(11.8)\end{array}$ & $\begin{array}{c}20.4 \\
(12.8)\end{array}$ & $\begin{array}{c}20.9 \\
(11.6)\end{array}$ & $\begin{array}{c}15.8 \\
(12.3)\end{array}$ \\
\hline $\begin{array}{l}\text { Years of } \\
\text { tenure }\end{array}$ & $\begin{array}{c}9.8 \\
(10.5)\end{array}$ & $\begin{array}{l}10.1 \\
(9.9)\end{array}$ & $\begin{array}{l}5.6 \\
(7.9)\end{array}$ & $\begin{array}{c}9.0 \\
(8.7)\end{array}$ & $\begin{array}{l}10.7 \\
(9.0)\end{array}$ & $\begin{array}{c}5.3 \\
(6.6)\end{array}$ & $\begin{array}{c}10.9 \\
(10.3)\end{array}$ & $\begin{array}{c}11.7 \\
(10.7)\end{array}$ & $\begin{array}{c}5.7 \\
(7.3)\end{array}$ \\
\hline $\begin{array}{l}\text { Years of } \\
\text { school }\end{array}$ & $\begin{array}{c}7.5 \\
(1.6)\end{array}$ & $\begin{array}{l}11.0 \\
(3.6)\end{array}$ & $\begin{array}{l}8.9 \\
(2.7)\end{array}$ & $\begin{array}{c}9.1 \\
(2.4)\end{array}$ & $\begin{array}{l}12.6 \\
(3.5)\end{array}$ & $\begin{array}{l}10.6 \\
(3.5)\end{array}$ & $\begin{array}{l}11.1 \\
(2.3)\end{array}$ & $\begin{array}{l}14.0 \\
(3.2)\end{array}$ & $\begin{array}{l}13.2 \\
(3.0)\end{array}$ \\
\hline $\begin{array}{l}\text { Private } \\
\text { sector }\end{array}$ & 0.761 & 0.489 & 0.755 & 0.577 & 0.456 & 0.660 & 0.589 & 0.482 & 0.847 \\
\hline
\end{tabular}


Table 4. Quantile Regressions: Union Dummies (Standard Errors in Parentheses)

\begin{tabular}{|l|c|c|c|c|}
\hline & $\begin{array}{c}10^{\text {th }} \\
\text { Percentile }\end{array}$ & $\begin{array}{c}\underline{50^{\text {th }}} \\
\text { Percentile }\end{array}$ & $\begin{array}{c}\underline{90^{\text {th }}} \\
\text { Percentile }\end{array}$ & $\underline{\text { OLS }}$ \\
\hline \multicolumn{5}{|c|}{$\begin{array}{c}2000 \\
(\mathrm{n}=2980)\end{array}$} \\
\hline LO & .053 & -.069 & -.480 & -.163 \\
& $(.017)$ & $(.015)$ & $(.030)$ & $(.015)$ \\
\hline TCO & .162 & .105 & -.129 & .050 \\
SACO & $(.017)$ & $(.015)$ & $(.030)$ & $(.015)$ \\
\hline Constant & 2.371 & 2.710 & 3.375 & 2.811 \\
& $(.014)$ & $(.013)$ & $(.025)$ & $(.013)$ \\
\hline \multicolumn{5}{|c|}{$(1981$} \\
& $(\mathrm{n}=3296)$ \\
\hline LO & .118 & .061 & -.288 & .021 \\
& $(.030)$ & $(.037)$ & $(.039)$ & $(.015)$ \\
\hline TCO & .223 & .198 & .033 & .203 \\
SACO & $(.031)$ & $(.039)$ & $(.041)$ & $(.016)$ \\
\hline Constant & 2.089 & 2.376 & 3.005 & 2.427 \\
& $(.026)$ & $(.033)$ & $(.034)$ & $(.013)$ \\
\hline \multicolumn{5}{|c|}{$(1968$} \\
& $(\mathrm{n}=2893)$ \\
\hline LO & .349 & .128 & -.311 & .098 \\
& $(.021)$ & $(.015)$ & $(.024)$ & $(.018)$ \\
\hline TCO & .465 & .441 & .242 & .425 \\
SACO & $(.024)$ & $(.017)$ & $(.028)$ & $(.021)$ \\
\hline Constant & 1.609 & 2.128 & 2.885 & 2.167 \\
& $(.016)$ & $(.011)$ & $(.019)$ & $(.014)$ \\
\hline
\end{tabular}


Table 5: Quantile Regressions - 2000 ( $n=2942$, SE in Parentheses)

\begin{tabular}{|l|c|c|c|c|}
\hline & $\begin{array}{c}10^{\text {th }} \\
\text { Percentile }\end{array}$ & $\begin{array}{c}\underline{50^{\text {th }}} \\
\text { Percentile }\end{array}$ & $\begin{array}{c}\underline{90^{\text {th }}} \\
\text { Percentile }\end{array}$ & $\underline{\text { OLS }}$ \\
\hline LO & .016 & -.064 & -.245 & -.115 \\
& $(.019)$ & $(.014)$ & $(.026)$ & $(.014)$ \\
\hline TCO/SACO & .101 & .045 & -.086 & .009 \\
& $(.018)$ & $(.014)$ & $(.030)$ & $(.014)$ \\
\hline Male & .107 & .147 & .180 & .160 \\
& $(.014)$ & $(.010)$ & $(.021)$ & $(.010)$ \\
\hline Experience & .013 & .017 & .021 & .019 \\
& $(.002)$ & $(.001)$ & $(.003)$ & $(.001)$ \\
\hline Exp^2/100 & -.023 & -.024 & -.027 & -.028 \\
& $(.004)$ & $(.003)$ & $(.006)$ & $(.003)$ \\
\hline Tenure & .004 & .002 & .000 & .002 \\
& $(.001)$ & $(.001)$ & $(.001)$ & $(.001)$ \\
\hline Yrs of School & .016 & .032 & .053 & .036 \\
& $(.003)$ & $(.002)$ & $(.004)$ & $(.002)$ \\
\hline Private & .042 & .098 & .133 & .107 \\
& $(.015)$ & $(.011)$ & $(.023)$ & $(.011)$ \\
\hline Constant & 1.994 & 1.994 & 2.087 & 1.960 \\
& $(.047)$ & $(.032)$ & $(.071)$ & $(.032)$ \\
\hline
\end{tabular}

Table 5: Quantile Regressions - 1981 ( $\mathrm{n}=3283$, SE in Parentheses)

\begin{tabular}{|l|c|c|c|c|}
\hline & $\begin{array}{c}10^{\text {th }} \\
\text { Percentile }\end{array}$ & $\begin{array}{c}50^{\text {th }} \\
\text { Percentile }\end{array}$ & $\begin{array}{c}\underline{90^{\text {th }}} \\
\text { Percentile }\end{array}$ & $\underline{\text { OLS }}$ \\
\hline LO & .099 & -.008 & -.150 & -.002 \\
& $(.016)$ & $(.011)$ & $(.029)$ & $(.014)$ \\
\hline TCO/SACO & .186 & .055 & -.115 & .070 \\
& $(.018)$ & $(.012)$ & $(.032)$ & $(.015)$ \\
\hline Male & .133 & .127 & .199 & .149 \\
& $(.012)$ & $(.008)$ & $(.020)$ & $(.010)$ \\
\hline Experience & .011 & .015 & .021 & .018 \\
& $(.002)$ & $(.001)$ & $(.003)$ & $(.001)$ \\
\hline Exp^2/100 & -.020 & -.024 & -.033 & -.029 \\
& $(.003)$ & $(.002)$ & $(.005)$ & $(.003)$ \\
\hline Tenure & .004 & .003 & .006 & .005 \\
& $(.001)$ & $(.001)$ & $(.001)$ & $(.001)$ \\
\hline Yrs of School & .014 & .030 & .045 & .032 \\
& $(.002)$ & $(.001)$ & $(.004)$ & $(.002)$ \\
\hline Private & -.037 & -.003 & .056 & .022 \\
& $(.012)$ & $(.008)$ & $(.020)$ & $(.010)$ \\
\hline Constant & 1.811 & 1.899 & 2.010 & 1.830 \\
& $(.037)$ & $(.022)$ & $(.063)$ & $(.028)$ \\
\hline
\end{tabular}


Table 5: Quantile Regressions - 1968 ( $\mathrm{n}=2797, \mathrm{SE}$ in Parentheses)

\begin{tabular}{|l|c|c|c|c|}
\hline & $\begin{array}{c}10^{\text {th }} \\
\text { Percentile }\end{array}$ & $\begin{array}{c}\underline{50^{\text {th }}} \\
\text { Percentile }\end{array}$ & $\begin{array}{c}\underline{90^{\text {th }}} \\
\text { Percentile }\end{array}$ & $\underline{\text { OLS }}$ \\
\hline LO & .158 & -.034 & -.165 & -.012 \\
& $(.021)$ & $(.017)$ & $(.026)$ & $(.016)$ \\
\hline TCO/SACO & .319 & .137 & -.005 & .157 \\
& $(.025)$ & $(.020)$ & $(.030)$ & $(.018)$ \\
\hline Male & .257 & .264 & .291 & .290 \\
& $(.019)$ & $(.015)$ & $(.022)$ & $(.014)$ \\
\hline Experience & .026 & .026 & .029 & .031 \\
& $(.002)$ & $(.002)$ & $(.003)$ & $(.002)$ \\
\hline Exp^2/100 & -.046 & -.044 & -.046 & -.053 \\
& $(.005)$ & $(.004)$ & $(.006)$ & $(.004)$ \\
\hline Tenure & .004 & .003 & .003 & .004 \\
& $(.001)$ & $(.001)$ & $(.001)$ & $(.001)$ \\
\hline Yrs of School & .043 & .054 & .077 & .061 \\
& $(.003)$ & $(.003)$ & $(.005)$ & $(.003)$ \\
\hline Private & -.062 & -.037 & -.037 & -.044 \\
& $(.020)$ & $(.016)$ & $(.022)$ & $(.014)$ \\
\hline Constant & 1.067 & 1.425 & 1.606 & 1.282 \\
& $(.048)$ & $(.037)$ & $(.058)$ & $(.034)$ \\
\hline
\end{tabular}


Table 6 - Raw versus Counterfactual Gaps

\begin{tabular}{|c|c|c|c|c|c|c|}
\hline $\begin{array}{c}5^{\text {th }} \\
\text { percentile }\end{array}$ & $\begin{array}{c}10^{\text {th }} \\
\text { percentile }\end{array}$ & $\begin{array}{c}25^{\text {th }} \\
\text { percentile }\end{array}$ & $\begin{array}{c}50^{\text {th }} \\
\text { percentile }\end{array}$ & $\begin{array}{c}75^{\text {th }} \\
\text { percentile }\end{array}$ & $\begin{array}{c}90^{\text {th }} \\
\text { percentile }\end{array}$ & $\begin{array}{c}95^{\text {th }} \\
\text { percentile }\end{array}$ \\
\hline \multicolumn{7}{|c|}{1981 versus 1968} \\
\hline \multicolumn{7}{|c|}{ Raw Real Log Wage Gap } \\
\hline $\begin{array}{c}.386 \\
(.021)\end{array}$ & $\begin{array}{c}.329 \\
(.013)\end{array}$ & $\begin{array}{c}.241 \\
(.008)\end{array}$ & $\begin{array}{c}.156 \\
(.009)\end{array}$ & $\begin{array}{c}.091 \\
(.012)\end{array}$ & $\begin{array}{c}.056 \\
(.019)\end{array}$ & $\begin{array}{c}.041 \\
(.025)\end{array}$ \\
\hline \multicolumn{7}{|c|}{ Counterfactual - 1981 X's and 1968 ß’s } \\
\hline $\begin{array}{c}.276 \\
(.018)\end{array}$ & $\begin{array}{c}.240 \\
(.011)\end{array}$ & $\begin{array}{c}.167 \\
(.007)\end{array}$ & $\begin{array}{c}.074 \\
(.007)\end{array}$ & $\begin{array}{c}.015 \\
(.010)\end{array}$ & $\begin{array}{c}.073 \\
(.016)\end{array}$ & $\begin{array}{c}.098 \\
(.022)\end{array}$ \\
\hline \multicolumn{7}{|c|}{2000 versus 1981} \\
\hline \multicolumn{7}{|c|}{ Raw Real Log Wage Gap } \\
\hline $\begin{array}{c}.252 \\
(.017)\end{array}$ & $\begin{array}{c}.233 \\
(.008)\end{array}$ & $\begin{array}{c}.235 \\
(.006)\end{array}$ & $\begin{array}{c}.248 \\
(.007)\end{array}$ & $\begin{array}{c}.263 \\
(.011)\end{array}$ & $\begin{array}{c}.269 \\
(.016)\end{array}$ & $\begin{array}{c}.267 \\
(.022)\end{array}$ \\
\hline \multicolumn{7}{|c|}{ Counterfactual Gap - 2000 X’s and 1981 ' 's } \\
\hline $\begin{array}{c}.199 \\
(.015)\end{array}$ & $\begin{array}{l}.174 \\
(.009)\end{array}$ & $\begin{array}{l}.164 \\
(.006)\end{array}$ & $\begin{array}{c}.166 \\
(.007)\end{array}$ & $\begin{array}{l}.170 \\
(.011)\end{array}$ & $\begin{array}{l}.166 \\
(.016)\end{array}$ & $\begin{array}{c}.163 \\
(.022)\end{array}$ \\
\hline
\end{tabular}


Figure 1: Kernel Densities: Real Log Wages

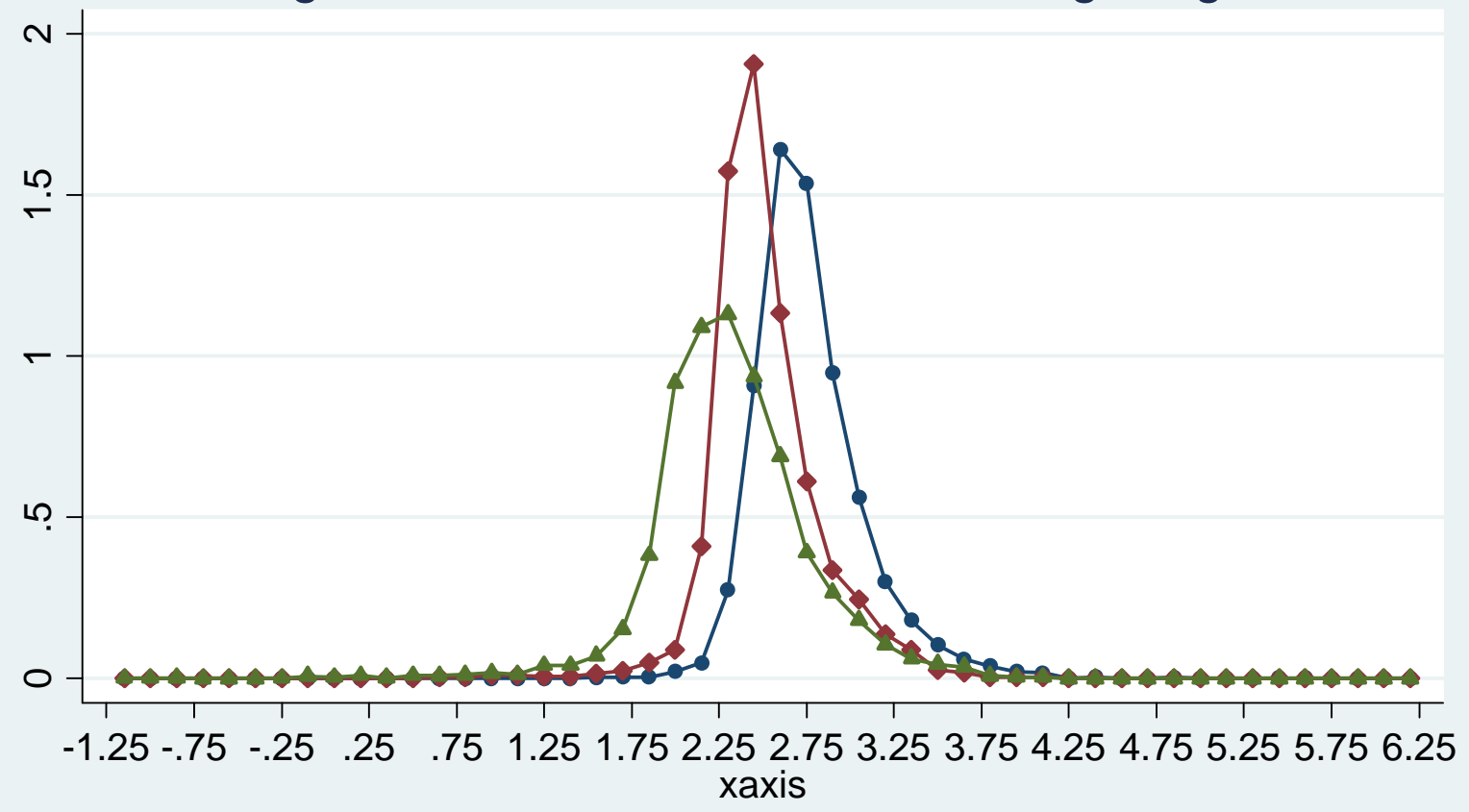

$\longrightarrow$ real log wage $2000 \longrightarrow$ real log wage 1981 real log wage 1968 
Figure 2: Real Log Wage Gap 1981/1968

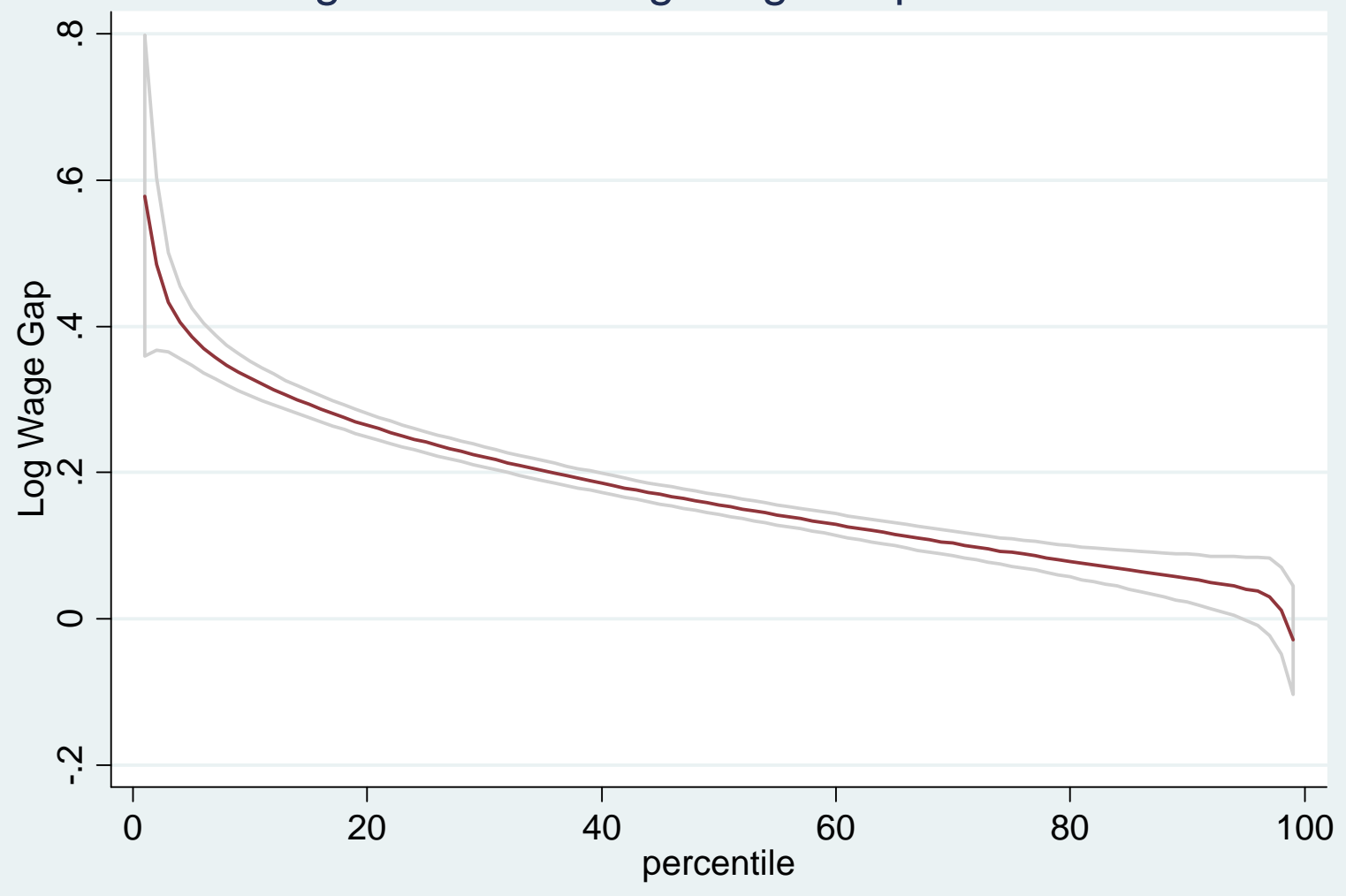


Figure 3: Real Log Wage Gap 2000/1981

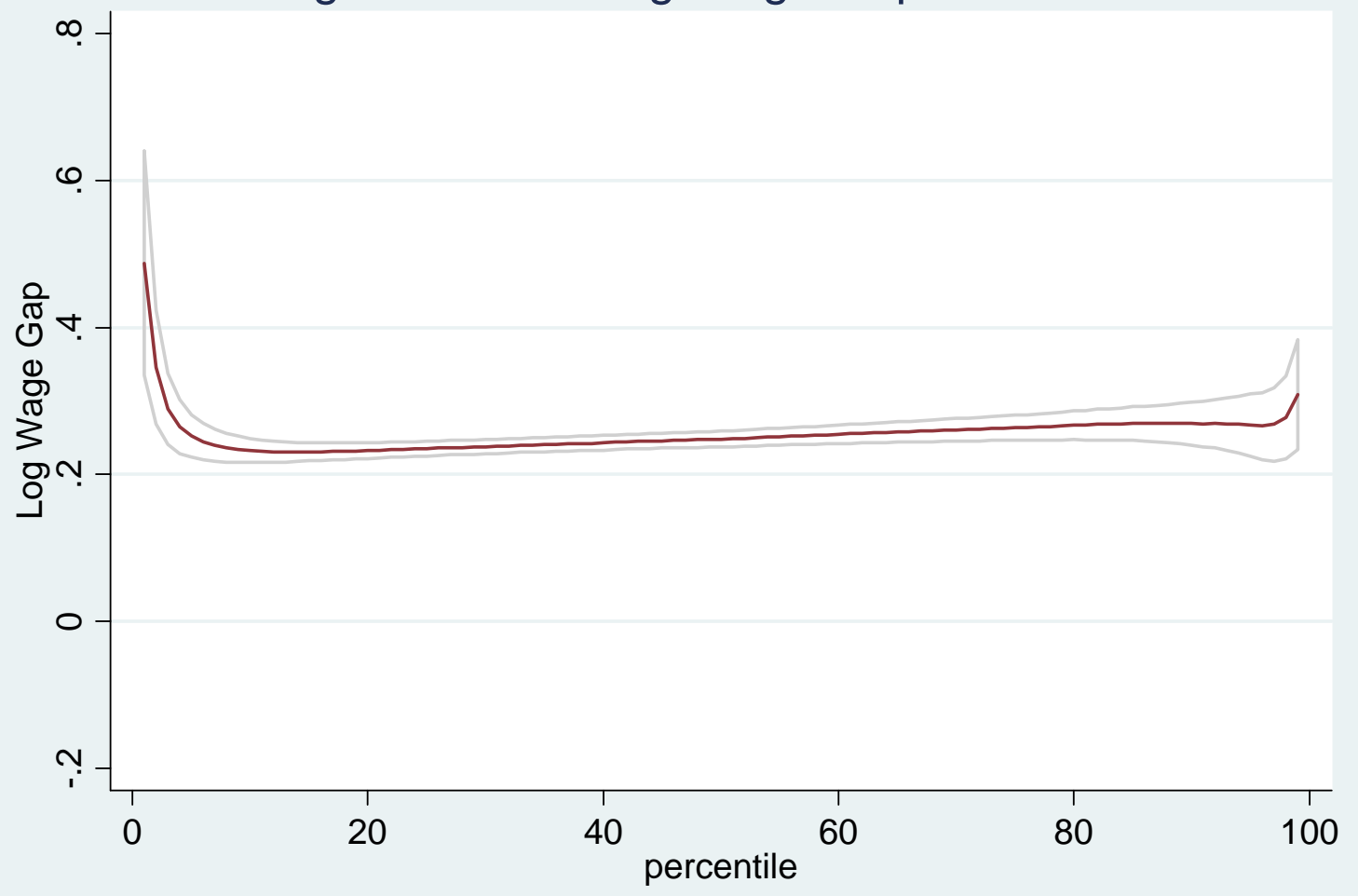


Fig 4: Real Log Wage Gap: 1981 vs 1981 with 1968 Returns

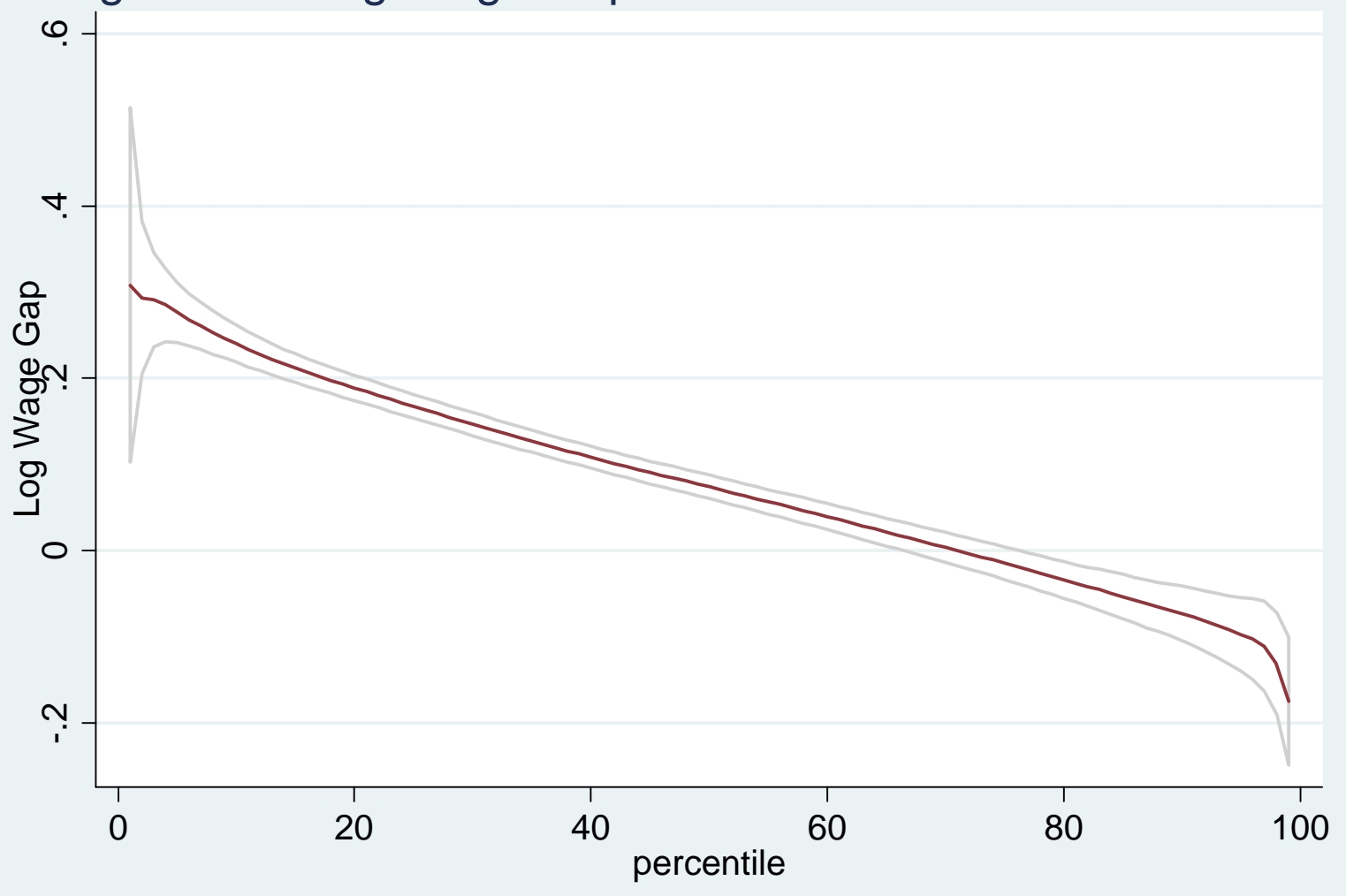


Fig 5: Real Log Wage Gaps 1981/1968: Decomposition
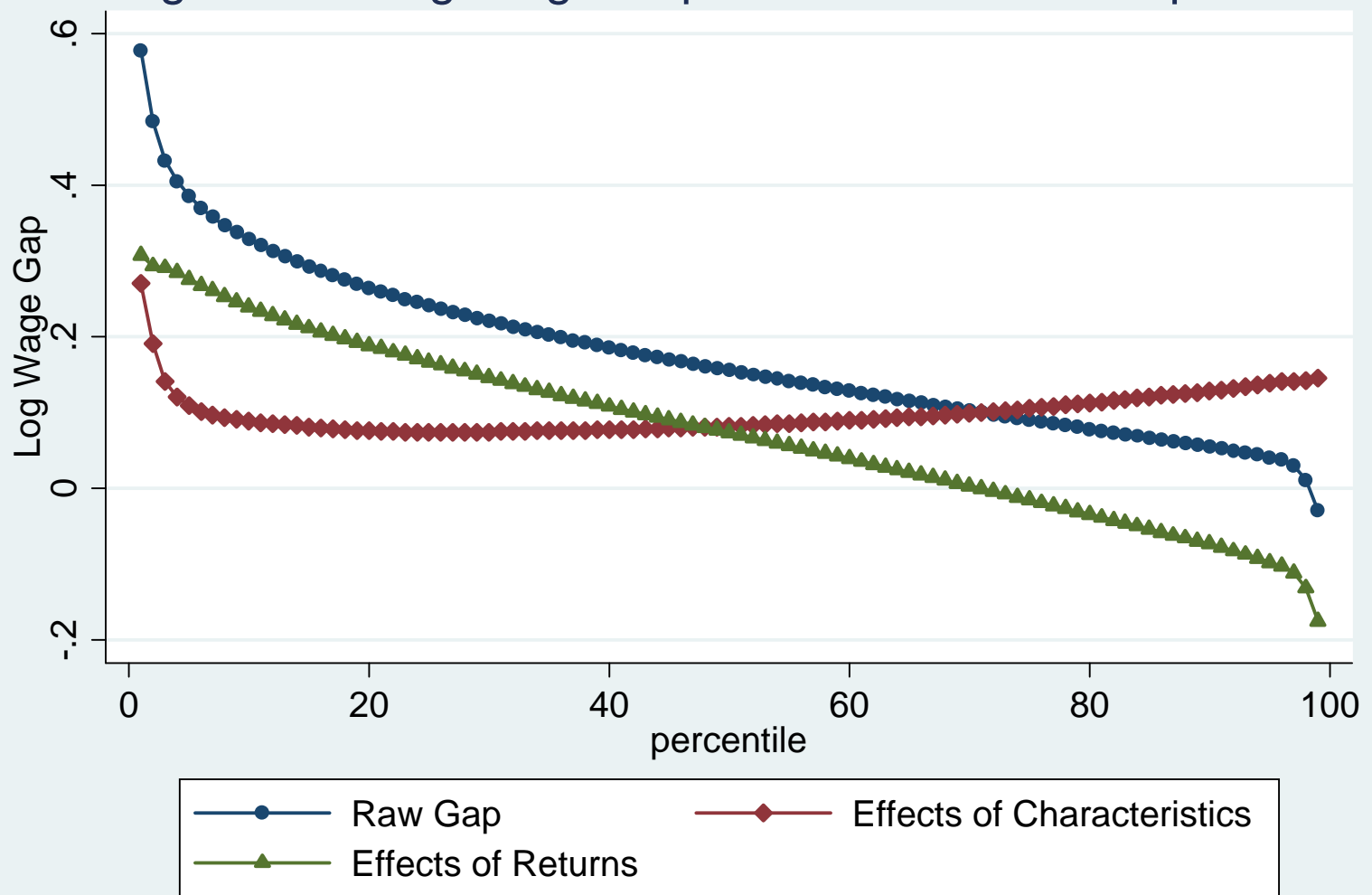

Fig 6: Real Log Wage Gap: 2000 vs 2000 with 1981 Returns

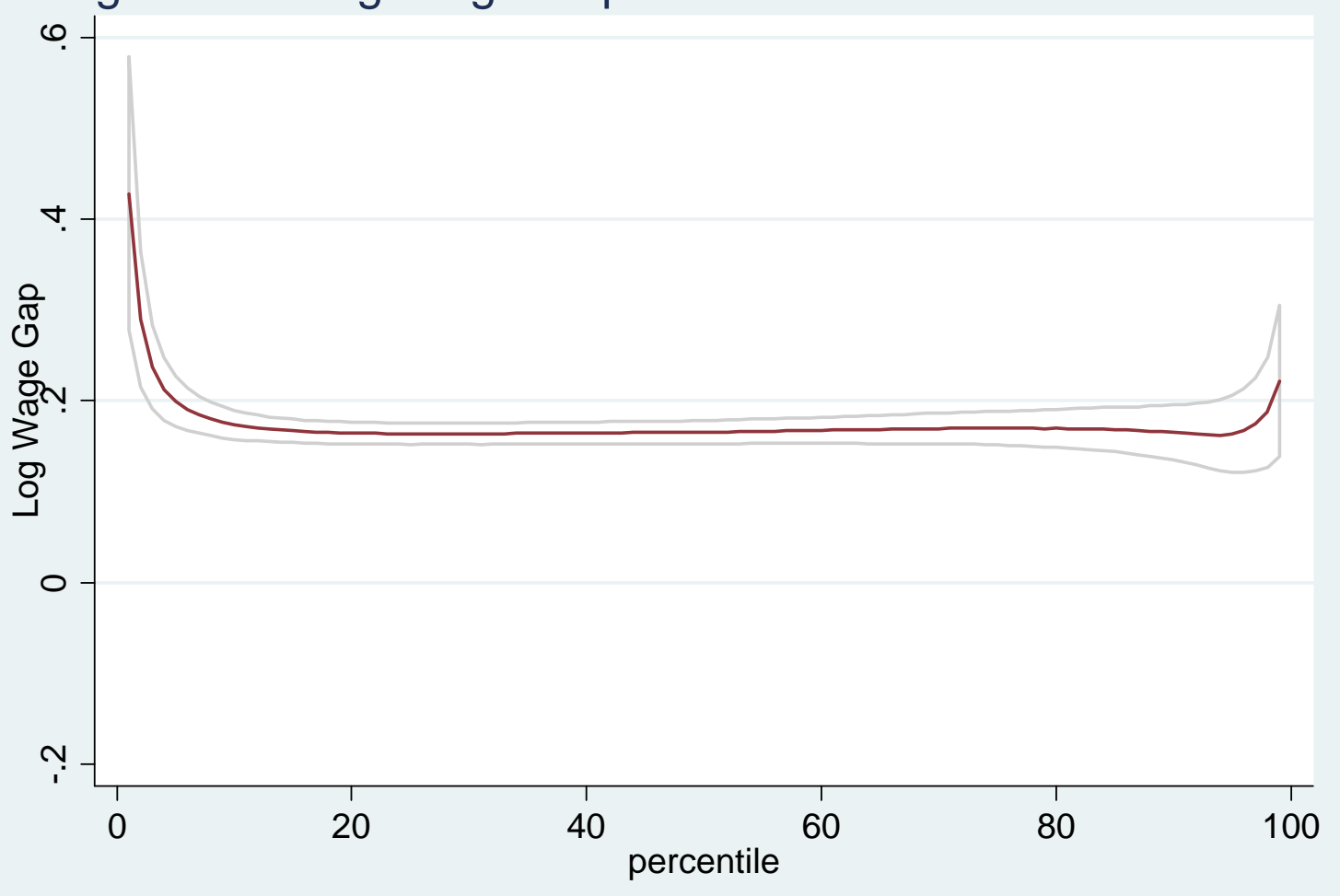


Fig 7: Real Log Wage Gaps 2000/1981: Decomposition

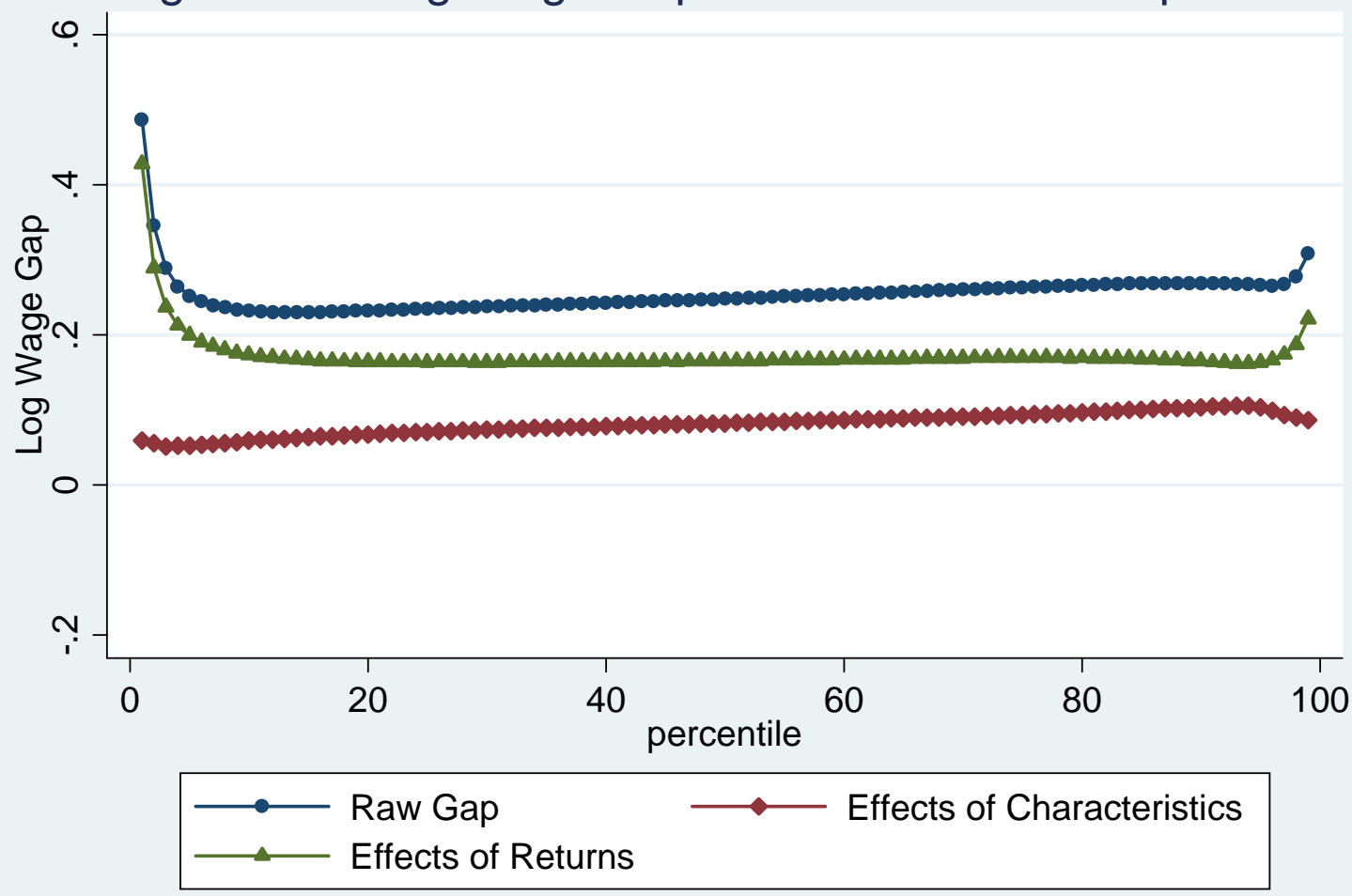

